\title{
THE EFFECT OF L-ARGININE ON OXIDATIVE STRESS AND MICROALBUMINURIA IN PATIENTS WITH TYPE 2 DIABETES MELLITUS AND CHRONIC KIDNEY DISEASE
}

\author{
L. P. Martynyuk, L. Z. Vons, O. O. Ruzhytska \\ I. HORBACHEVSKY TERNOPIL STATE MEDICAL UNIVERSITY, TERNOPIL, UKRAINE
}

Background. Diabetic kidney disease (DKD) is one of the severest complications of diabetes. Microalbuminuria (MAU) is one of the first signals of DKD and an important pathogenetic mechanism of disease progression. With diabetes antioxidant properties worsen significantly.

Objective. The aim was to investigate the effect of L-arginine on oxidative stress parameters and microalbuminuria in type 2 diabetes mellitus and chronic kidney disease patients.

Methods. In total, 57 patients with type 2 diabetes mellitus and chronic kidney disease and 30 healthy individuals (control group) took part in the study. The patients were divided into 2 congruent groups. The 1-st group of patients $(n=33)$, in addition to standard therapy, received L-arginine $4.2 \mathrm{~g}$ intravenously for 5 days, after that they took it $1.0 \mathrm{~g}$ orally three times a day during meals for 1 month. The second group of patients $(n=24)$ received a standard therapy.

The concentration of lipid peroxidation products was measured by a spectrophotometric method. The determination of MAU was carried out in morning portion of urine immunological semiquantitative using test strips.

Results. Significant improvement in indexes of lipid peroxidation was observed in both groups after therapy $(p<0.01)$, but in patients treated with L-arginine it was more expressed $(p<0.01)$. The standard therapy did not significantly affect the level of MAU ( $p>0.05)$. The patients treated with L-Arginine, showed a significant reduction in MAU ( $p<0.01)$.

Conclusions. L-arginine facilitates the correction of lipid peroxidation processes and reduces the severity of microalbuminuria in patients with diabetic kidney disease that slows down its progression.

KEY WORDS: diabetes mellitus, chronic kidney disease, lipid peroxidation, microalbuminuria, L-arginine.

\section{Introduction}

In recent decades a number of patients with diabetes mellitus (DM) is increased, the patients with type 2 diabetes mellitus are a significant share of them $[1,2,3]$.

Diabetic kidney disease (DKD) is one of the severest complications of diabetes; it is registered in $20-30 \%$ of patients with diabetes. Among the patients, who receive renal replacement therapy, the share of people with DKD is about $40-50 \%[2,4]$. It is established that 10 $20 \%$ of patients with diabetes die from chronic renal failure $[4,5]$.

Microalbuminuria (MAU) is one of the first signals of DKD. It is not only the symptoms but also an important pathogenetic mechanism of progression $[6,7]$. According to recent studies,

Corresponding author: Liudmula Vons, Department of Internal Medicine №3, I. Horbachevsky Ternopil State Medical University, 1 Clinichna Street, Ternopil, Ukraine, 46002

Phone number: +380965406768

E-mail:vonsluyda@gmail.com
MAU is considered to be an independent predictor of progressive renal disease [6, 7]. Despite the fact that MAU is regarded as a risk factor, in the timely diagnosis and adequate treatment it can achieve the level of recourse normoalbuminuric $[6,8]$. But in $30-45 \%$ of patients over 10 years old the disease progresses to proteinuria. On the other hand, in $20 \%$ of patients over 20 years old a terminal kidney failure is developing either $[6,7]$.

With diabetes antioxidant properties worsen significantly. The activity of antioxidant defence in the tissues is reduced; a lipid peroxidation is disordered that has repeatedly been proven in experimental diabetes $[9,10]$. It is important to reveal as soon as possible the disorders of pro- and antioxidant system for diagnosis and monitoring of the health state. The timely correction of changes can prevent the progression of vascular complications of diabetes [9]. 
The aim of our research was to investigate the effect of L-arginine on oxidative stress parameters and microalbuminuria in type 2 diabetes mellitus and chronic kidney disease patients.

\section{Methods}

A total of 57 patients with type 2 diabetes mellitus and I-V stages of chronic kidney disease took part in the study. There were $27(47 \%)$ men and 30 (53\%) women among them. The average age of the patients was $(58.7 \pm 1.2)$ years old. The average duration of diabetes is $(11.4 \pm 0.9)$ years. The average illness period of CKD is $(2.5 \pm 0.3)$ years. The average weight of patients was $(81.7 \pm 1.4) \mathrm{kg} .30$ healthy individuals composed the control group.

The diagnosis was established by the Second National Congress which was adopted as Nephrology classification of diseases of the urinary system in 2005. The stage of CKD was determined by glomerular filtration rate (GFR), defined by the formula CKD-EPI [11].

The concentration of thiobarbituric acid reactive substances (TBARS) was determined in the blood serum by a spectrophotometric method [12]. We also evaluated the concentrations of glutathione (SH-group) [13], catalase [14], superoxide dismutase (SOD) [15] in the blood plasma.

The determination of MAU was carried out in morning portion of urine immunological semiquantitative using test strips CLINITEK $®$ Microalbumin 2 Strips (Germany) by means of the unit CLINITEK Status ${ }^{\circledR}+$ Analyser (Germany). MAU was diagnosed at the level of urinary albumin excretion within $30-300 \mathrm{mg} /$ day, normoalbuminuria - less than $30 \mathrm{mg} /$ day.

The patients with DKD were divided into 2 congruent groups: the 1-st group of patients $(n=33)$, who, in addition to standard therapy

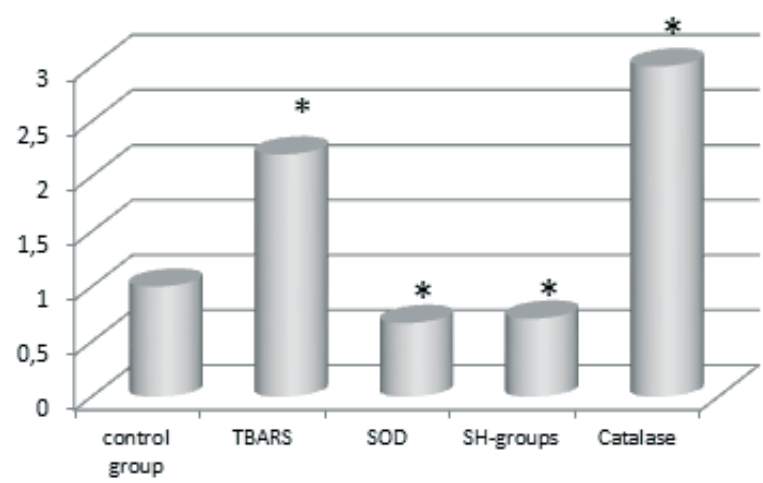

Fig. 1. The level of lipid peroxidation indexes in DKD patients before treatment and control groups.

* - The difference between the control group and DKD patients group is significant $(p<0.01)$. received L-arginine $4.2 \mathrm{~g}$ intravenously for 5 days, after that they took it $1.0 \mathrm{~g}$ orally three times a day during meals for 1 month. The second group of patients $(n=24)$ received a standard therapy. The results were compared with those of the healthy controls ( $n 30$ ).

The data were subjected to statistical research processing. For this purpose the application package Statistica (StartSoft USA, v.12) was used: the method of parametric and nonparametric statistics, Spearman rank correlation to determine the connection between the studied parameters. Statistically significant differences in $p<0.05$ are considered.

\section{Results}

Analyzing the results, it was found outthat $100 \%$ of patients with DKD have lipid peroxidation disorders (Fig. 1).

The average level of MAU in the DKD patients before treatment is in 25.6 times higher than in the control group (Fig. 2).

We have analysed the findings of MAU, depending on the method of treatment in DKD patients groups before and after treatment (Table 2).

\section{Discussion}

The average levels of TBARS and SH-groups in the patients with DKD before treatment were significantly increased compared with the corresponding values in the control group $(p<0.01)$. Significantly reduced SOD and catalase activity were detected in the observed DKD patients before treatment compared with the control group $(p<0.01)$. No significant difference in lipid peroxidation indexes was noted between two DKD patients groups before treatment ( $p>0.05)$. Significant improvement in lipid peroxidation indexes was observed in both DKD patients groups after therapy $(p<0.01)$, but in the pa-

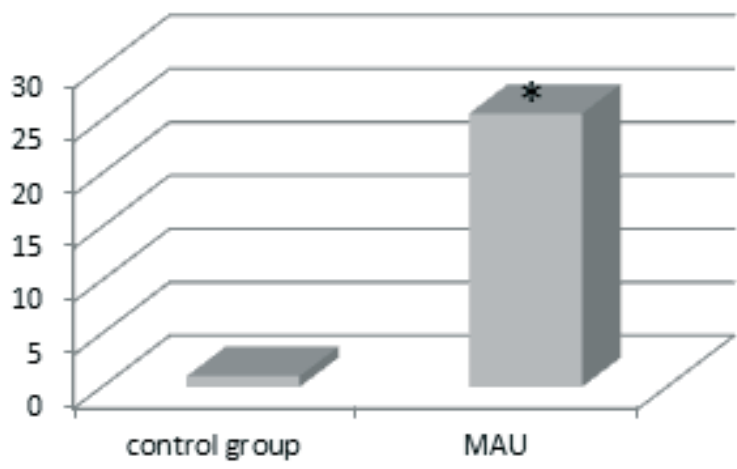

Fig. 2. The level of MAU in the DKD patients before treatment and in the control groups.

* - The difference between the control group and the DKD patients group is significant $(p<0.01)$ 
The effects of treatment on lipid peroxidation indexes are presented in Table 1.

Table 1. The dynamics of lipid peroxidation indexes in DKD patients before and after treatment depending on different treatment regimens, $\mathrm{M} \pm \mathrm{m}$

\begin{tabular}{|c|c|c|c|c|c|c|}
\hline \multirow{2}{*}{\multicolumn{2}{|c|}{ Indexes }} & \multicolumn{2}{|c|}{ Groups } & \multicolumn{3}{|c|}{$\mathrm{p}$} \\
\hline & & \multirow{2}{*}{$\begin{array}{c}\begin{array}{c}\text { Group I } \\
(n=33)\end{array} \\
6.26 \pm 0.20\end{array}$} & \multirow{2}{*}{$\begin{array}{c}\begin{array}{c}\text { Group II } \\
(n=24)\end{array} \\
6.20 \pm 0.13\end{array}$} & \multirow{2}{*}{$\begin{array}{c}p_{1} \\
p>0.05\end{array}$} & \multirow[t]{2}{*}{$p_{2}$} & \multirow[t]{2}{*}{$p_{3}$} \\
\hline $\begin{array}{l}\text { TBARS, } \\
\mathrm{mkmol} / \mathrm{l}\end{array}$ & $\begin{array}{c}\text { Before } \\
\text { treatment }\end{array}$ & & & & & \\
\hline & $\begin{array}{c}\text { After } \\
\text { treatment }\end{array}$ & $3.81 \pm 0.27$ & $5.27 \pm 0.46$ & $p<0.01$ & $p<0.01$ & $p<0.05$ \\
\hline \multirow[t]{2}{*}{$\begin{array}{c}\text { SOD, } \\
\%\end{array}$} & $\begin{array}{c}\text { Before } \\
\text { treatment }\end{array}$ & $41.76 \pm 0.68$ & $41.45 \pm 0.66$ & $p>0.05$ & & \\
\hline & $\begin{array}{c}\text { After } \\
\text { treatment }\end{array}$ & $55.61 \pm 1.42$ & $43.21 \pm 1.18$ & $p<0.01$ & $p<0.01$ & $p>0.05$ \\
\hline \multirow[t]{2}{*}{$\begin{array}{c}\text { SH-groups, } \\
\mathrm{mlmol} / \mathrm{l}\end{array}$} & $\begin{array}{c}\text { Before } \\
\text { treatment }\end{array}$ & $42.59 \pm 1.23$ & $43.71 \pm 2.08$ & $p>0.05$ & & \\
\hline & $\begin{array}{c}\text { After } \\
\text { treatment }\end{array}$ & $57.05 \pm 1.98$ & $51.14 \pm 1.65$ & $p<0.05$ & $p<0.01$ & $p<0.05$ \\
\hline \multirow[t]{2}{*}{$\begin{array}{c}\text { Catalase, } \\
\%\end{array}$} & $\begin{array}{c}\text { Before } \\
\text { treatment }\end{array}$ & $53.74 \pm 2.16$ & $51.46 \pm 1.18$ & $p>0.05$ & & \\
\hline & $\begin{array}{c}\text { After } \\
\text { treatment }\end{array}$ & $31.39 \pm 2.80$ & $47.25 \pm 2.88$ & $p<0.01$ & $p<0.01$ & $p>0.05$ \\
\hline
\end{tabular}

Notes:

1. $p_{1}$ - significant difference in performance between groups before and after treatment.

2. $p_{2}$ - significant difference in performance in the first group before and after treatment.

3. $p_{3}$ - significant difference in performance in the second group before and after treatment.

Table 2. The dynamics of MAU levels, depending on different treatment regimens, $M \pm m$

\begin{tabular}{|l|c|c|c|c|c|}
\hline \multirow{2}{*}{$\begin{array}{c}\text { MAU } \\
\text { mg/day }\end{array}$} & \multicolumn{2}{|c|}{ Groups } & \multicolumn{2}{c|}{$\mathrm{p}$} & $\mathrm{p}_{3}$ \\
\cline { 2 - 6 }$(\mathrm{n}=23)$ & $180.7 \pm 19.9$ & $\begin{array}{c}\text { Group II } \\
(\mathrm{n}=24)\end{array}$ & $\mathrm{p}_{1}$ & $\mathrm{p}>0.05$ & $\mathrm{p}>0.05$ \\
\hline $\begin{array}{l}\text { Before } \\
\text { treatment }\end{array}$ & $51.4 \pm 15.6 \pm 15.6$ & $149.2 \pm 15.5$ & $\mathrm{p}<0.01$ & $\mathrm{p}<0.01$ & $\mathrm{p}$ \\
\hline $\begin{array}{l}\text { After } \\
\text { treatment }\end{array}$ & & & & & \\
\hline
\end{tabular}

Notes:

1. $p_{1}$ - significant difference in performance between groups before and after treatment.

2. $\mathrm{p}_{2}$ - significant difference in performance in the first group before and after treatment.

3. $p_{3}$ - significant difference in performance in the second group before and after treatment.

tients treated with L-arginine it was more expressed $(p<0.01)$.

The standard therapy did not significantly affect the level of MAU ( $p>0.05)$. A significant reduction in MAU $(p<0.01)$ was proved in the patients treated with L-Arginine.

The role of oxidative stress in the pathogenesis of diabetes has been examined repeatedly in the experimental models. Renal cortical superoxide production is increased in the early stage of experimental diabetes that leads to vasoconstriction of afferent arteriole [16]. Recent studies in experimental models of diabetic nephropathy indicate that vascular synthesis of NO protects from progression of renal lesions in diabetes [17]. L-arginine is a semiessential amino acid and also the main source for the generation of NO via nitric oxide synthase [18].

Recent study demonstrated that L-arginine supplementation in type II diabetic rats was beneficial by preserving glomerular filtration rates, presumably via increased renal endothelial nitric oxide synthase levels, that leads to renal vasodilation [19].

In our present research L-arginine supplementation, which stimulates nitric oxide synthesis, causes a pronounced improvement in lipid peroxidation indexes and a significant reduction in MAU in the patients with DKD.

\section{Conclusions}

In patients with DKD, the decrease in activity of SOD and catalase and the increase of TBARS 
and $\mathrm{SH}$-group parameters is observed that proved a lipid peroxidation disorder.

L-arginine in the standard therapy facilitates the correction of lipid peroxidation processes and reduces the severity of microalbuminuria in patients with diabetic kidney disease that slows down its progression.

\section{References}

1. Schieppati A. Chronic renal disease as a public health problem: epidemiology, social and economic implications. Kidney Int. 2005;98:7-10.

2. Dudar I, Loboda O, Korol L, Alieksieieva V. Progression of chronic kidney disease and the role of oxidative stress in different stages of CKD. Ukrainian Journal of Nephrology and Dialysis. 2012; 2(34):18-24.

3. Gaidaiev Yu. Endocrinological state service of Ukraine and prospects of medical care to patients with endocrine disorders. International Journal of Endocrinology. 2006;2(4):9-14.

4. Kamynsky A. Diabetes: new insights and old misconceptions. Part 2. Prevention of type 2 diabetes. International Journal of Endocrinology. 2012;4:42-45.

5. Kolesnyk M. Endocrinology: Science and Practice. Pharmacist. 2008;3:4-6.

6. Loboda OM, Krasyuk IV, Alexeeva VV, Korol LV, Driyanska VY, Dudar IO. The relationship of lipid peroxidation and chronic inflammation of atherosclerotic changes in vessels and poeaznykamy endothelial dysfunction in patients with CKD stages II-IV. Ukrainian journal of Nephrology and dialysis. 2015;1(45):13-20.

7. Sirenko Yu. New Opportunities determination of microalbuminuria in clinical practice. Hypertension. 2010;3(11):55-58.

8. Caramori M. The need for early predictors of diabetic nephropathy risk: is albumin excretion rate sufficient. Diabetes. 2000;9:1399-1408.

9. Radzyshevsky N. Violation of homeostasis and oxidative carbohydrate metabolism and their effects on the heart and blood vessels in patients with comorbid diseases. Therapeutic Ukrainian magazine. 2016;1:30-35.

10. Reheda M, Bayda M. Role of disorders of lipid peroxidation and activity of antioxidant enzymes in the trachea of guinea pigs in the pathogenesis of allergic alveolitis ekspyrymentalnoho and their correction Thiotriazolin. Experimental and clinical physiology. 2013;1:47-52.

11. Levey AS, Stevens LA, Schmid CH, Zhang YL, Castro AF, Feldman HI, et al. A New Equation to Estimate Glomerular Filtration Rate. Ann Intern Med. 2009;150:604-612.

12. Gavrilov V, Mishkorudnaya M. Spectrophotometric determination of lipid hyperoxides in blood plasma. Laboratornoe delo. 1983;29:33-35.

13. Ellman GL. Tissue sulfhydryl groups. Arch Biochem. 1959;82:70-72.

14. Koroluy M, Ivanova L, Majorova I. Metod opredeleniya aktivnosti katalazi. Laboratornoe delo. 1988;34:16-19.

15. Chevari S, Andyal T, Shtrenger YA. Determination of antioxidant parameters of blood and their significance in old age. Laboratornoe delo. 1991;37:9-13.

16. Ishii N, Patel KP, Lane PH, Taylor T, Bian K, Murad F, et al. Nitric oxide synthesis and oxidative stress in the renal cortex of rats with diabetes mellitus. J Am Soc Nephrol. 2001;12:1630-1639.

17. KanetsunaY, Takahashi K, Nagata M, Gannon MA, Breyer MD, Harris RC, et al. Deficiency of endothelial nitric-oxide synthase confers susceptibility to diabetic nephropathy in nephropathyresistant inbred mice. Am J Pathol. 2007;170(5): 1473-84.

18. Cherla G, Jaimes EA. Role of L-arginine in the pathogenesis and treatment of renal disease. J Nutr. 2004;134(10):2801-2806.

19. Claybaugh T, Decker S, McCall K, Slyvka Y, Steimle J, et al. L-Arginine Supplementation in Type II Diabetic Rats Preserves Renal Function and Improves Insulin Sensitivity by Altering the Nitric Oxide Pathway. Int J Endocrinol. 2014:171546. doi: $10.1155 / 2014 / 171546$

Received: 2016-12-07 